Anna Moszyńska

Uniwersytet Mikołaja Kopernika w Toruniu e-mail: moszynska.anna@gmail.com telefon: +4856 6114053

DOI: $10.15290 / \mathrm{mhi} .2015 .14 .02 .09$

\title{
Prace nad kodyfikacją majątkowego prawa cywilnego w latach 1950-52
}

\author{
SUMMARY \\ Works on the Codification of the Property Civil Law in the Years 1950-52
}

This article attempts to answer the question of how works on the codification of civil law proceeded, following the political upheaval of 1948. The literature indicates that the work was interrupted and that another project of the Civil Code was not published until 1954. Codification efforts were indeed broken, but in September 1950 the Presidium of the Government adopted a significant resolution requiring the Minister of Justice to prepare a draft of the Civil Code in just 11 months. The author - on the basis of archival documents - is trying to reconstruct the course of this work and fill gaps in the existing literature. It turns out that the Ministry of Justice accomplished the resolution, even though the set time limit may have seemed unreal. By the end of August 1951 the project of the Civil Code with its reasons was finished. However, in view of the advanced work on a new constitution, the project was suspended and legislative work has not been continued.

Key words: codification of the civil law, the draft of the Civil Code, Civil Law Codification Commission, Ministry of Justice

Slowa kluczowe: kodyfikacja prawa prywatnego, projekt kodeksu cywilnego, Komisja Kodyfikacji Prawa Cywilnego, Ministerstwo Sprawiedliwości

Zagadnienie kodyfikacji prawa cywilnego po II wojnie światowej było wielokrotnie poruszane w literaturze przedmiotu przez Profesora Adama Lityńskiego ${ }^{1}$. Jego liczne publikacje stanowią nieocenione źródło wiedzy dla każ-

\footnotetext{
* Praca naukowa sfinansowana ze środków Uniwersytetu Mikołaja Kopernika w ramach indywidualnego grantu badawczego nr 1955-P.

1 Tytułem przykładu: A. Lityński, Pierwszy etap prac nad kodyfikacja prawa cywilnego w Polsce Ludowej (szkic dla dydaktyki), [w:] Z dziejów prawa, Katowice 1999, cz. 2, s. 194-205; idem, Na drodze do
} 
dego historyka prawa. Niniejszy artykuł, inspirowany twórczością Pana Profesora, stanowi próbę odpowiedzi na pytanie, jak potoczyły się prace kodyfikacyjne po przełomie politycznym, który nastąpił w $1948 \mathrm{r}$. W literaturze wskazuje się, że prace te zostały zahamowane ${ }^{2}$, a kolejny projekt kodeksu cywilnego (k.c.) został opublikowany dopiero 5 lat później. Jednak we wrześniu 1950 r. Prezydium Rządu podejmuje znamienną uchwałę zobowiązującą ministra sprawiedliwości do przygotowania projektu k.c. w przeciągu zaledwie jedenastu miesięcy. Niewiele wiemy o przebiegu tych prac, a także o tym, czy udało się dopełnić tego niewiarygodnego terminu. Nawet ówcześnie żyjący wybitni naukowcy, jak również sami uczestnicy prac kodyfikacyjnych, pomijają milczeniem to, co działo się w latach 1949-1953, wskazując, że pierwszy po przesileniu politycznym projekt ukazał się drukiem dopiero $\mathrm{w} 1954 \mathrm{r}^{3}$

Po udanym dziele unifikacji prawa cywilnego przystąpiono do kodyfikacji tego prawa. Dnia 15 grudnia 1946 r. odbyła się uroczysta akademia z okazji ukończenia unifikacji prawa cywilnego ${ }^{4}$. Zaledwie dwa miesiące później - 18 lutego 1947 r. minister sprawiedliwości powołał specjalną Komisję do opracowania jednolitego polskiego kodeksu cywilnego ${ }^{5}$, zwaną też często Komisją Kodyfikacyjną Prawa Cywilnego ${ }^{6}$. Komisja na przestrzeni 1947 i 1948 r. przygotowała projekty poszczególnych ksiąg kodeksu cywilnego, często okre-

kodyfikacji prawa cywilnego w Polsce Ludowej, [w:] Prawo wczoraj $i$ dziś. Studia dedykowane profesor Katarzynie Sójce-Zielińskiej, Warszawa 2000, s. 135-153; idem, Prawo cywilne materialne w Polsce Ludowej, [w:] Pót wieku kodyfikacji prawa w Polsce (1919-1969). Wybrane zagadnienia, Tychy 2001, s. $87-99$.

2 Z. Radwański, Prawo cywilne PRL, "Czasopismo Prawno-Historyczne” (dalej: CPH) 1995, z. 1-2, s. 24; A. Lityński, O prawie i sq̨dach początków Polski Ludowej, Białystok 1999, s. 227; L. Górnicki, Kodyfikacja prawa prywatnego, [w:] System Prawa Prywatnego, t. 1, Prawo cywilne - część ogólna, red. M. Safjan, Warszawa 2012, s. 148-149.

3 S. Szer, Prawo spadkowe, Warszawa 1955, s. 14; J. Gwiazdomorski, Prawo spadkowe w zarysie, Warszawa 1967, s. 22; W. Czachórski, Przebieg prac nad kodyfikacja prawa cywilnego PRL, „Studia Prawnicze" 1970, z. 26-27, s. 8.

4 Z okazji zakończenia unifikacji prawa cywilnego (akademia), "Demokratyczny Przegląd Prawniczy" (dalej: DPP) 1947, nr 1-2, s. 12-19. W zbiorach Narodowego Archiwum Cyfrowego (dalej: NAC) znajduje się też nagranie dźwiękowe tej uroczystości - Transmisja uroczystości poświęconej zakończeniu prac nad unifikacja prawa cywilnego w Polsce, odbywajacej się w gmachu Prezydium Rady Ministrów w Warszawie, NAC, Zespół nagrań dźwiękowych 33-P-787 (P. Kowalski, Z badań nad prawem spadkowym w projekcie kodeksu cywilnego z 1948 r., „Miscellanea Historico-Iuridica” (dalej: MHI) 2013, t. XII, s. 261, przypis 1).

5 Zarządzenie Ministra Sprawiedliwości w sprawie powotania komisji do opracowania jednolitego polskiego kodeksu cywilnego. Tekst zarządzenia został opublikowany przez P. Fiedorczyka w: Dokumenty archiwalne dotyczace organizacji prac nad unifikacja $i$ kodyfikacja polskiego prawa cywilnego w latach 1945-1948, MHI 2006, t. IV, s. 166.

6 Takim zwrotem posługiwano się w szczególności w późniejszych sprawozdaniach z prac Ministerstwa Sprawiedliwości (np. Archiwum Akt Nowych, zespół nr 285 - Ministerstwo Sprawiedliwości w Warszawie, teczka 5605, karta 27, dalej cytowane następująco: AAN 285, t. 5605, k. 27) oraz protokołach posiedzeń Komisji (np. AAN 285, t. 2380, k. 80). Por. też P. Fiedorczyk, Unifikacja i kodyfikacja prawa rodzinnego w Polsce (1945-1964), Białystok 2014, s. 286. 
Ślane łącznie jako pierwszy projekt kodeksu cywilnego ${ }^{7}$. Podkreślenia wymaga, że ten pierwszy projekt był dziełem niewielkiej - zaledwie kilkuosobowej - Komisji ${ }^{8}$.

Dalsze prace kodyfikacyjne zahamował jednak przełom polityczny, który nastąpił w 1948 r. Na sierpniowo-wrześniowym plenum KC PPR „zdemaskowano i zlikwidowano odchylenie prawicowo-nacjonalistyczne $\mathrm{w}$ partii" ${ }^{\prime \prime}$. W konsekwencji nastąpiła przyspieszona stalinizacja wszystkich dziedzin życia państwowego - $\mathrm{w}$ tym prawa cywilnego ${ }^{10}$. Z przyczyn podanych jedynie ogólnikowo do wiadomości publicznej, przerwano prace nad gotowym projektem k.c. i całkowicie zmieniono koncepcję prac kodyfikacyjnych ${ }^{11}$.

Jednocześnie dokonano istotnych zmian $\mathrm{w}$ organizacji wszelkich prac legislacyjnych. Uchwałą Rady Ministrów z dnia 11 grudnia 1948 r. Komisję Prawniczą, do której zadań należało m.in. ustalenie ostatecznej redakcji projektów aktów prawnych, przeniesiono ze struktur Ministerstwa Sprawiedliwości do Prezydium Rządu ${ }^{12}$. Co istotne, uchwała w ogóle nie wspominała o działającej od prawie 2 lat Komisji Kodyfikacyjnej Prawa Cywilnego. W literaturze wskazuje się, że świadczyło to o podjętej już decyzji o przerwaniu prac tej komórki i oznaczało fiasko pierwszej próby kodyfikacji prawa w Polsce Ludowej ${ }^{13}$.

Rzeczywiście, Komisja proceduje jeszcze nadal, ale niedługo później zaprzestaje działalności. Jeszcze w marcu J. Witecki przysyła swój projekt dotyczący ostatniej księgi kodeksu cywilnego - prawa spadkowego ${ }^{14}$, a w kolejnym liście poprawki do jednego z artykułów projektu księgi drugiej ${ }^{15}$. Na liście tym

Zob. np. W. Czachórski, op. cit., s. 8.

8 Przewodniczącym Komisji został minister sprawiedliwości Henryk Świątkowski, jego stałymi zastępcami byli Stefan Bancerz, Seweryn Szer i Aleksander Wolter, sekretarzem Komisji zaś został Witold Czachórski. Pozostałymi członkami Komisji byli: Jan Wasilkowski, Marian Lisiewski, Jan Witecki. W grudniu 1948 r. - a więc krótko przed zakończeniem tego etapu prac Komisji - jej grono zostało powiększone o dwóch sędziów SN: Maurycego Grudzińskiego i Jerzego Marowskiego (P. Kowalski, op. cit., s. 265).

9 A. Lityński, O prawie $i$ sądach..., s. 226. Idem, Dwie wielkie transformacje prawa sadowego w Polsce XX wieku. Koncepcje i ich realizacja, [w:] W pię́setlecie Konstytucji Nihil Novi. Z dziejów stanowienia prawa $w$ Polsce, Warszawa 2006, s. 125.

10 A. Lityński, Nowe ustawodawstwo w nowym ustroju. O prawie karnym i cywilnym w pierwszym dwudziestoleciu Polski Ludowej, MHI 2006, t. IV, s. 135.

11 S. Grodziski, Prace nad kodyfikacja i unifikacja polskiego prawa prywatnego (1919-1947), „Kwartalnik Prawa Prywatnego" (dalej: KPP) 1992, z. 1-4, s. 28; idem, Z dziejów unifikacji polskiego prawa cywilnego, CPH 1985, z. 2, s. 299.

12 Uchwała Rady Ministrów RP o trybie uzgadniania i uchwalania projektów ustaw, dekretów i rozporzadzeń opublikowana przez: P. Fiedorczyk, J. Volkonovski, Organizacja prac legislacyjnych Rady Ministrów w świetle niepublikowanej uchwały Rady Ministrów z 11 grudnia 1948 r., MHI 2011, t. X, s. 298-303.

13 P. Fiedorczyk, J. Volkonovski, op. cit., s. 296.

14 AAN 285, t. 2181, k. 2-33; zob. więcej: P. Kowalski, op. cit., s. 261-276.

15 List Jana Witeckiego z dnia 14 marca 1949 r. (AAN 285, t. 2181, k. 1). 
widnieje odręczna notatka o udzielonej J. Witeckiemu odpowiedzi, iż obrady nad prawem spadkowym będą miały miejsce $\mathrm{w}$ kwietniu. Prawdopodobnie to zaplanowane posiedzenie Komisji już się nie odbyło.

Nie oznacza to jednak całkowitego przerwania prac nad prawem cywilnym. W kwietniu i kolejnych miesiącach 1949 r. prace te trwają nadal. Nie toczą się jednak w Komisji Kodyfikacyjnej Prawa Cywilnego, lecz w Departamencie Ustawodawczym Ministerstwa Sprawiedliwości, a dokładnie w znajdującym się w jego strukturze Wydziale Prawa Cywilnego. Projekty przygotowane $\mathrm{w}$ Wydziale były przekazywane Komisji Prawniczej ${ }^{16}$. Prace kodyfikacyjne koncentrują się jednak na przygotowaniu do wprowadzenia $\mathrm{w}$ życie wspólnego polsko-czechosłowackiego projektu kodeksu prawa rodzinnego ${ }^{17}$. Wymagało to skonstruowania wielu dalszych przepisów, koniecznych do zharmonizowania projektu $\mathrm{z}$ innymi działami prawa cywilnego ${ }^{18}$. Równolegle podjęto też prace nad przygotowaniem nowych przepisów ogólnych prawa cywilnego, "celem stworzenia wspólnej i dostosowanej do obecnej sytuacji politycznej, gospodarczej i społecznej nadbudówki dla wszystkich działów prawa prywatnego" 19

Od wiosny 1949 r. nie toczyły się już prace nad innymi działami prawa cywilnego: prawem rzeczowym, obligacyjnym i spadkowym. O pracach nad kodeksem cywilnym w tym okresie nie mogło więc być mowy. Prace nad tym aktem przerwano na półtora roku ${ }^{20}$. Wznowiono je we wrześniu 1950 r., lecz nowe działania kodyfikacyjne nie obejmują już uchwalonego prawa rodzinnego oraz przepisów ogólnych ${ }^{21}$. Zamierzenia koncentrują się wokół pozostałych działów prawa cywilnego - określanych wspólnym mianem „majątkowego prawa cywilnego". Ta wspólna terminologia miała podkreślać odrębność tych działów od stosunków osobistych uregulowanych w prawie rodzinnym.

16 Sprawozdanie z prac Wydziału Prawa Cywilnego w III kwartale 1949 r. (AAN 285, t. 5633, k. 35).

17 Projekt został opracowany przez specjalną wspólną komisję polsko-czechosłowacką, w skład której wchodzili także pracownicy Wydziału Prawa Cywilnego (zob. szerzej: P. Fiedorczyk, Unifikacja i kodyfikacja..., s. 145-251).

18 W Wydziale Cywilnym toczyły się prace m.in. nad zaprojektowaniem zmian do k.p.c., przygotowaniem projektu postępowania niespornego z zakresu postępowania przed władzą opiekuńczą, prawa o aktach stanu cywilnego, przepisów wprowadzających kodeks rodzinny (Sprawozdanie z prac Wydziału Prawa Cywilnego za IV kwartał 1949 r., AAN 285, t. 5633, k. 51).

19 Sprawozdanie z dnia 12 lipca 1949 r. z prac Wydziału Prawa Cywilnego w II kwartale 1949 r. (AAN 285, t. 5633, k. 16).

20 P. Fiedorczyk przyjmuje ostrożnie jako datę przerwania prac połowę 1949 r. (P. Fiedorczyk, Unifikacja i kodyfikacja..., s. 147). W Wydziale Prawa Cywilnego już w II kwartale 1949 r. nie toczą się żadne prace nad majątkowym prawem cywilnym, prawdopodobnie więc prace nad kodeksem cywilnym zamarły w kwietniu 1949 r. (Sprawozdanie z prac Wydziału Prawa Cywilnego w II kwartale 1949 r., AAN 285, t. 5633, k. 220-221).

21 Kodeks rodzinny uchwalono 27 czerwca 1950 r. (Dz. U. Nr 34, poz. 308), a 18 lipca tegoż roku przepisy ogólne prawa cywilnego (Dz. U. Nr 34, poz. 311). 
Istotnym impulsem rozpoczynającym nowy etap prac kodyfikacyjnych była znana uchwała Prezydium Rządu z dnia 27 września 1950 r. uznająca opracowanie nowych kodeksów Polski Ludowej - karnego i cywilnego - za sprawę „pilną i konieczną"22. Jednocześnie zobowiązano ministra sprawiedliwości do opracowania projektów obu kodeksów w rekordowo krótkim czasie - do 1 września $1951 \mathrm{r}$. Mniej natomiast znanym faktem jest to, że geneza tej uchwały - a zwłaszcza niezwykle krótkiego terminu - związana jest z wcześniejszym memoriałem ministra sprawiedliwości „W sprawie kodyfikacji prawa cywilnego" skierowanym właśnie do Prezydium Rządu ${ }^{23}$.

Pismo to powstaje we wrześniu w Ministerstwie Sprawiedliwości. Dokładna data dzienna nie jest znana, ale jego przygotowanie musiało nastąpić przed 21 września, skoro od przedstawienia tego memoriału rozpoczęto posiedzenie Komisji Kodyfikacyjnej Prawa Cywilnego w tym dniu ${ }^{24}$. Wstęp pisma łudząco przypomina treść późniejszej uchwały Prezydium Rządu: „Ministerstwo Sprawiedliwości wysuwa sprawę kodyfikacji prawa cywilnego, jako zagadnienie pilne i doniosłe $\mathrm{z}$ punktu widzenia dostosowania tego działu ustawodawstwa i opartej na nim praktyki wymiaru sprawiedliwości do potrzeb i zadań naszego ustroju". W piśmie czuć wyraźnie ducha przemian, jakie dokonały się w życiu politycznym: "Zdaniem Ministerstwa reforma ta będzie miała także istotne znaczenie dla rozwoju marksistowskiej nauki prawa" i dalej: „kodyfikacja prawa cywilnego stałaby się niewątpliwie momentem przełomowym $\mathrm{w}$ rozwoju polskiej nauki tego działu prawa, kierując ją zdecydowanie na tory marksistowskie". Co jednak najważniejsze w kontekście niniejszych rozważań, minister wskazał, że „opracowanie projektu kodeksu

22 Uchwała Prezydium Rządu w sprawie opracowania nowych kodeksów Polski Ludowej-karnego i cywilnego (Monitor Polski Nr A-106, poz. 1339). Uchwałę opublikowano także w organie prasowym Ministerstwa Sprawiedliwości („Nowe Prawo” 1950, nr 10, s. 2). Na uwagę zasługuje fakt, iż pismo od tego numeru zmieniło nazwę z "Demokratycznego Przeglądu Prawniczego" na "Nowe Prawo" (dalej: NP). Jednocześnie powołano też nowy komitet redakcyjny, uznając wyżej wymienioną uchwałę oraz przeprowadzoną w 1950 r. reformę wymiaru sprawiedliwości za wydarzenia rozpoczynające nową epokę w rozwoju systemu prawnego Polski Ludowej (zob. wyjaśnienie redakcji opublikowane pod tytułem „Nowe Prawo”, NP 1950, nr 10, s. 1-2). Por. także: J. Skąpski, Kodeks cywilny z 1964 r. Blaski i cienie kodyfikacji oraz jej perspektywy, KPP 1992, z. 1-4, s. 62; Uchwała Prezydium Rządu dotyczaca prac kodyfikacyjnych, „Państwo i Prawo” (dalej: PiP) 1951, z. 1, s. 67. O skali dokonanych zmian świadczy wymownie tytuł artykułu, który ukazał się w kolejnym numerze NP: Pomoc, przykład, przyjaźn ZSRR drogowskazem naszych prac kodyfikacyjnych (NP 1950, nr 11, s. 5-6).

O piśmie tym wspomina P. Fiedorczyk w: Unifikacja i kodyfikacja..., s. 146 i 286. W AAN zachowały się dwie wersje tego pisma - wcześniejsza (AAN 285, t. 2190, k. 1-5) i późniejsza z drobnymi zmianami (ibidem, k. 6-10). Na żadnej z tych wersji nie widnieje parafa ministra, a jedynie maszynowo wypisane miejsce na jego podpis. Żadnej z tych wersji nie opatrzono też datą dzienną sporządzenia pisma - w nagłówku wskazano jedynie wrzesień $1950 \mathrm{r}$.

24 Protokót z konferencji Komisji Kodyfikacyjnej Prawa Cywilnego w dniu 21.IX.1950 r. w Ministerstwie Sprawiedliwości (AAN 285, t. 2382, k. 52-56). 
cywilnego może nastąpić do 1 lipca 1951 r." Jest to termin szokująco krótki - dziewięciomiesięczny - nawiązujący być może do identycznego okresu zakreślonego na dokonanie unifikacji ${ }^{25}$, którego - przypomnijmy na marginesie - nie udało się dotrzymać.

Szybko okazuje się, że termin ten nie jest realny do spełnienia. Wydana jeszcze w tym samym miesiącu uchwała Prezydium Rządu wyznacza okres o zaledwie 2 miesiące dłuższy. Nadal jednak termin wydaje się niemożliwy do zrealizowania, zwłaszcza iż nowy etap kodyfikacji nie może ograniczać się do technicznego połączenia prawa zunifikowanego, lecz ma oznaczać jego głęboką przebudowę w kierunku modelu marksistowskiego. Dlatego prace nad opracowaniem projektu kodeksu cywilnego Polski Ludowej rozpoczęto w Ministerstwie Sprawiedliwości niezwłocznie - jeszcze we wrześniu 1950 r. ${ }^{26}$, część podjętych działań nawet antycypowała przełomową uchwałę Prezydium Rządu. W pierwszym okresie - do grudnia 1950 r. - prace polegały na gromadzeniu i analizie materiałów naukowych, statystycznych oraz informacyjnych ${ }^{27}$. Rozesłano ankiety do sądów, notariuszy i prezydiów rad narodowych dotyczące praktycznej oceny poszczególnych zagadnień prawa cywilnego. Skompletowano również materiały z zakresu prac nad kodyfikacją prawa cywilnego w ZSRR, Czechosłowacji i Bułgarii ${ }^{28}$.

$\mathrm{Na}$ początkowym etapie prac kwitła nadal współpraca z południowymi sąsiadami - Czechosłowacy w tym samym 1950 r. uchwalili kodeks cywilny. Odbyły się dwie konferencje z prawnikami czechosłowackimi - jedna w Polsce $^{29}$, druga w Czechosłowacji - na temat wymiany wzajemnych doświadczeń odnośnie kodyfikacji prawa cywilnego ${ }^{30}$.

Finalnym efektem pierwszej fazy prac kodyfikacyjnych było opracowanie projektów tez ogólnych prawa rzeczowego, spadkowego i zobowiązań. $\mathrm{W}$ ostatecznej wersji sprawozdania z przebiegu prac kodyfikacyjnych, jakie minister H. Świątkowski złożył do Prezydium Rządu, wskazano, że projekty tez ogólnych zostały opracowane na podstawie uprzednio zebranych mate-

Por. uchwała Rady Ministrów z dnia 12 czerwca 1945 r. w sprawie unifikacji prawa cywilnego, tekst w: P. Fiedorczyk, Dokumenty archiwalne..., s. 165.

26 Sprawozdanie Departamentu Ustawodawczego z prac w zakresie kodyfikacji prawa karnego i cywilnego (AAN 285, t. 5605, k. 30).

27 Ibidem, k. 30-33.

28 Przetłumaczono kodeks cywilny radziecki z 1947 r., kodeks cywilny czechosłowacki z uzasadnieniem z 1950 r., kodeks cywilny bułgarski, zebrano materiały dotyczące rolniczych spółdzielni produkcyjnych z państw demokracji ludowej (Bułgaria, Czechosłowacja, Rumunia). Teksty tłumaczeń tych kodeksów znajdują się w zasobach AAN.

29 Pierwsza konferencja odbyła się w Sopocie i koncentrowała się przede wszystkim wokół zagadnień prawa rzeczowego (Departament Ustawodawczy. Wydziat Prawa Cywilnego. Sprawozdanie z wykonania planu prac za II kwartat 1950 r.; AAN 285, t. 2362, k. 27). 
riałów, przede wszystkim uzyskanych z ZSRR (głównie kodeksów innych państw bloku socjalistycznego) ${ }^{31}$. Z projektu sprawozdania natomiast wynika, że tłumaczenie zagranicznych kodeksów odbywało się równolegle z przygotowywaniem tez ogólnych do poszczególnych części polskiego kodeksu cywilnego ${ }^{32}$. Tłumaczenie niektórych aktów trwało jeszcze w pierwszych miesiącach 1951 r. ${ }^{33}$, tymczasem w grudniu 1950 r. gotowe już były projekty tez ogólnych wszystkich działów majątkowego prawa cywilnego. Należy więc przyjąć, że przepisy socjalistycznych kodeksów nie miały decydującego wpływu na przygotowywane tezy.

Na jesieni 1950 r. prace wznawia również Komisja Kodyfikacyjna Prawa Cywilnego ${ }^{34}$. Po opracowaniu projekty tez ogólnych kierowane był pod jej obrady i następnie przez nią uchwalane. Komisja w 1950 r. odbyła trzy posiedzenia plenarne. Pierwsze posiedzenie Komisji Kodyfikacyjnej ma miejsce 21 września 1950 r. - a więc jeszcze przed znaczącą uchwałą Prezydium Rządu ${ }^{35}$. Otwiera je wicedyrektor Departamentu Ustawodawczego - Seweryn Szer, rozpoczynając od zapoznania członków Komisji z treścią pisma i memoriału, jakie Ministerstwo Sprawiedliwości wystosowało do Prezydium Rządu odnośnie kodyfikacji prawa cywilnego. Poza S. Szerem, udział w konferencji wzięły jedynie trzy osoby - dwaj członkowie z poprzedniego składu Komisji: Jan Wasilkowski i Jerzy Marowski" ${ }^{36}$, oraz nowy członek - Jan Topiński (prezes Głównej Komisji Arbitrażowej). Szybko pada więc wniosek o poszerzenie składu Komisji - Jan Wasilkowski zaproponował powiększenie grona do siedmiu osób. Liczebnie Komisja miała więc powrócić do stanu sprzed półtora roku, jej skład personalny nie został jednak całkowicie powtórzony. Propozycja J. Wasilkowskiego dotyczyła włączenia do składu Komisji przedstawicieli obrotu gospodarki socjalistycznej, gdyż w obecnej sytuacji byli oni „zmajoryzowani przez «sądowników»"37. Skład Komisji miał więc odzwierciedlać drastyczne zmiany, jakie dokonały się w życiu gospodarczym.

Głównym celem spotkania było opracowanie metody i planu pracy Komisji - po długiej dyskusji co do metod procedowania, członkowie dokonują

Sprawozdanie z przebiegu prac kodyfikacyjnych za czas od 1 października do 31 grudnia 1950 r. (AAN 285, t. 5605, k. 20). AN 285, t. 5605, k. 16

Sprawozdanie z przebiegu prac kodyfikacyjnych w I kwartale 1951 r. (AAN 285, t. 2362, k. 80-82).

Kwestia czy Komisja ta stanowiła kontynuację posiedzeń Komisji powołanej uchwałą z dnia 18 lutego 1947 r., czy też stanowiła nowy podmiot, wymaga dalszych badań. Przebieg pierwszego posiedzenia, odzwierciedlony we wskazanym poniżej protokole, przemawia za poglądem o kontynuacji prac.

35 Protokót z konferencji Komisji Kodyfikacyjnej Prawa Cywilnego w dniu 21.IX.1950 r. w Ministerstwie Sprawiedliwości (AAN 285, t. 2382, k. 52-56). 
"prowizorycznego" podziału prac między siebie ${ }^{38}$. Na kolejne posiedzenie Komisji członkowie - zwani już od tego momentu referentami - zobowiązali się przygotować wstępne tezy do powierzonych im partii materiału.

Członkowie - po zapoznaniu z memoriałem ministra sprawiedliwości wskazują na nierealność terminu zakończenia prac kodyfikacyjnych do połowy 1951 r. ${ }^{39}$ Celem prac ma być jednak nie stworzenie idealnego kodeksu, lecz szybkie dostosowanie prawa do nowej rzeczywistości politycznej. Jan Wasilkowski nie ma żadnych wątpliwości, że przygotowywany kodeks cywilny nie będzie tworem trwałym: „Nie mam złudzeń co do tego, abyśmy mogli stworzyć kodeks na dłuższy okres czasu" ${ }^{\prime 4}$. Ta gorzka konstatacja zapewne wynika z doświadczeń z prac nad pierwszym projektem kodeksu, który szybko okazał się "anachronizmem" jeszcze przed jego ukończeniem ${ }^{41}$. Szybkie uchwalenie kodeksu cywilnego Jan Wasilkowski uważał jednak za konieczność, nawet gdyby miał niedługo obowiązywać. Pozwoli to bowiem, „wyjść z «tradycyjnego» wleczenia się w ogonie zjawisk życia społecznego"42.

W trakcie prac kodyfikacyjnych Wydział Prawa Cywilnego współpracował też z utworzoną niewiele wcześniej Komisją Konsultacyjno-Naukowąą3. Współpraca ta dotyczyła w szczególności przygotowania materiałów pomocniczych do kodyfikacji oraz opracowania referatów z zakresu prawa cywilnego

38 Janowi Wasilkowskiemu przypadło prawo rzeczowe, delikty w prawie obligacyjnym i ogólny współudział przy zobowiązaniach. Jan Topiński miał zająć się problematyką przedsiębiorstw państwowych, wkładem obrotu socjalistycznego do zobowiązań oraz "spuścizną" po prawie handlowym. Seweryn Szer miał się skupić przede wszystkim na prawie spadkowym, w zakresie prawa zobowiązań zaś na planach gospodarczych jako źródle powstania zobowiązań. Zagadnienia z zakresu majątkowego prawa cywilnego rozdzielono więc między trzech członków Komisji, gdyż dalszy udział w jej pracach Jerzego Marowskiego pozostawał jeszcze pod znakiem zapytania. Jak wynika z protokołu ",Z uwagi na przeciążenie pracą w SN, brak asystentów i słaby stan zdrowia Sędzia Marowski prosi o danie mu kilku dni do namysłu co do ewentualnego udziału w pracach Komisji" (AAN 285, t. 2382, k. 53, 55-56).

Jan Topiński uważał, że termin zakończenia prac Komisji należy przesunąć na październik $1951 \mathrm{r}$. Seweryn Szer zaś wskazywał, że chyba czynione są starania o przedłużenie terminu (AAN 285, t. 2382, k. 55). AAN 285, t. 2382, k. 53.

Jan Wasilkowski w 1950 r. w następujący sposób odnosił się do pierwszego projektu k.c.: „wobec postępującej $\mathrm{w}$ gwałtownym tempie rewolucyjnej przebudowy społecznej $\mathrm{w}$ kierunku socjalizmu - okazało się wkrótce, że cel prac kodyfikacyjnych został określony niewłaściwie i że wskutek tego kodeks opracowany według planu z 1947 r. byłby anachronizmem już w chwili ogłoszenia. Stało się oczywistym, że prawo cywilne polskie - jeśli ma być czynnikiem prawdziwego postępu, czynnikiem ułatwiającym i przyspieszającym budowę ustroju socjalistycznego - wymaga przede wszystkim zasadniczej rewizji swych założeń ideologicznych" (idem, Kodyfikacja prawa cywilnego $w$ Polsce, NP 1950, nr 12, s. 4). Ta wypowiedź głównego redaktora projektu stanowiła samokrytykę (zob. ibidem, s. 4, przypis 2). AAN 285, t. 2382, k. 53.

43 Komisja Konsultacyjno-Naukowa została powołana 30 września 1949 r. Do zadań Komisji należała konsultacja i pomoc teoretyczna w zagadnieniach kodyfikacyjnych (zob. P. Fiedorczyk, Unifikacja i kodyfikacja..., s. 287). 
na zjazdy teoretyków i praktyków ${ }^{44}$. W ten sposób posiedzenia Komisji Konsultacyjno-Naukowej od jesieni 1950 r. koncentrowały się przede wszystkim na kodyfikacji prawa ${ }^{45}$.

W nowym 1951 r. nastąpiła kolejna faza prac kodyfikacyjnych. Plan pracy Wydziału Prawa Cywilnego na ten rok całkowicie zdominowała kwestia przygotowania projektu kodeksu cywilnego ${ }^{46}$. Pracom towarzyszyła ciągła presja czasu. Naczelnik Wydziału Seweryn Szer na początku roku deklarował, że do 1 września 1951 r. Wydział stosownie do uchwały Prezydium Rządu opracuje projekt kodeksu cywilnego ${ }^{47}$.

W pierwszej kolejności przystąpiono do opracowywania szczegółowych tez prawa rzeczowego, spadkowego i zobowiązaniowego. Stanowiły one rozwinięcie wcześniej przygotowanych tez ogólnych, po ich przeanalizowaniu przez Komisję Kodyfikacyjną.

Jeszcze pod koniec poprzedniego roku Komisja zajęła się tezami ogólnymi prawa rzeczowego, uchwalając je $\mathrm{w}$ grudniu $1950 \mathrm{r}$. Następnie, na początku 1951 r., Komisja rozpatrywała tezy ogólne prawa zobowiązaniowego oraz problematykę wynikającą z zamierzonego uchylenia kodeksu handlowego ${ }^{48}$. Najpóźniej Komisja zajęła się projektem tez ogólnych prawa spadkowego. Na podstawie uchwał Komisji opracowano projekty szczegółowych tez prawa rzeczowego, zobowiązaniowego i spadkowego wraz z uzasadnieniami ${ }^{49}$. Miały one stanowić podstawę do przygotowania artykułowanych projektów tych części kodeksu. Równolegle opracowywano skrócone tezy „dla czynników nadrzędnych" 50 .

Po zaakceptowaniu tez szczegółowych, w dalszej fazie prac kodyfikacyjnych opracowywano projekty wstępne wszystkich trzech działów prawa majątkowego cywilnego. W ten sposób - jak wskazywano w sprawozdaniu za II kwartał 1951 r. ${ }^{51}$ - Wydział Prawa Cywilnego zdążył opracować

44 Plan pracy Wydziału Prawa Cywilnego na 1951 r. (AAN 285, t. 2362, k. 59); Sprawozdanie z wykonania planu pracy Wydziału Prawa Cywilnego za rok 1951 (AAN 285, t. 2362, k. 131).

45 Na początku 1951 r. postanowiono m.in., że od marca odbywać się będą comiesięczne sesje naukowe, na których w pierwszej kolejności miały być przedyskutowane tematy kodyfikacyjne (Protokót z posiedzenia Prezydium Komisji Konsultacyjno-Naukowej przy Ministerstwie Sprawiedliwości odbytego w dniu 12 lutego 1951 r., AAN 285, t. 5465, k. 11).

Plan pracy Wydziału Prawa Cywilnego na 1951 r. (AAN 285, t. 2362, k. 59).

47 Ibidem.

48 Na posiedzeniu Komisji Kodyfikacyjnej Prawa Cywilnego w dniu 18 stycznia 1951 r. i 8 lutego 1951 r. (AAN 285, t. 2362, k. 67 i 83).

49 Sprawozdanie z przebiegu prac kodyfikacyjnych $w$ I kwartale 1951 . Ministra Sprawiedliwości H. Świątkowskiego adresowane do Prezydium Rządu (AAN 285, t. 2362, k. 80-82).

50 AAN 285, t. 5605, k. 35.

51 Sprawozdanie z wykonania planu prac Wydziału Prawa Cywilnego za kwartał II r. 1951 (AAN 285, t. 2362, k. 100), por. z: Plan pracy Wydziału Prawa Cywilnego na II kwartał 1951 r. (AAN 285, t. 2362, k. 83). 
pierwszą redakcję projektu kodeksu cywilnego, a dokładnie części dotyczącej prawa rzeczowego, obligacyjnego i spadkowego. Co zrozumiałe, ówczesne prace kodyfikacyjne nie dotyczyły części ogólnej, świeżo uchwalonej w 1950 r. Nie podejmowano też prac nad prawem rodzinnym, wyodrębnionym w osobny kodeks $\mathrm{w}$ tym samym roku. Względy polityczne $\mathrm{w}$ tym okresie zaważyły nad zwycięstwem koncepcji odrębnej regulacji prawa rodzinnego ${ }^{52}$.

W rzeczywistości do czerwca $1951 \mathrm{r}$. opracowana została nie pierwsza redakcja projektu kodeksu cywilnego, lecz projekty poszczególnych działów majątkowego prawa cywilnego. Prace nad nimi toczyły się odrębnie, osobno wysyłano projekty do konsultacji i uzgodnień. Kolejność prac przedstawiała się następująco: po opracowaniu wstępnego projektu poddawano go pod obrady Komisji Kodyfikacyjnej Prawa Cywilnego oraz Komisji Konsultacyjno-Naukowej. Po uwzględnieniu uwag obu komisji powstawała kolejna wersja projektu. Wersję tę rozsyłano do wszystkich ministerstw oraz do Zrzeszenia Prawników Polskich, w którego gronie przeprowadzano dyskusję nad projektem.

Wydział Prawa Cywilnego współpracował w trakcie prac kodyfikacyjnych z Komisją Konsultacyjno-Naukową. Przed przystąpieniem do opracowywania wstępnego projektu prawa rzeczowego Komisja ta zorganizowała konferencję teoretyków i praktyków prawa w celu przedyskutowania najważniejszych zagadnień z zakresu prawa rzeczowego ${ }^{53}$. Wyniki dyskusji zostały wzięte pod uwage $\mathrm{w}$ trakcie przygotowywania projektu prawa rzeczowego ${ }^{54}$.

Wiele wątpliwości wywołał też wstępny projekt prawa obligacyjnego opracowany przez A. Chełmońskiego. Na konferencji Komisji Kodyfikacyjnej Prawa Cywilnego przedstawiono ustnie tak wiele zastrzeżeń, że zobowiązano jej członków do zgłoszenia w ciągu 14 dni dodatkowych uwag na piśmie. Po ich przesłaniu został opracowany drugi projekt $\mathrm{z}$ uwzględnieniem zarówno uwag ustnych, jak i pisemnych ${ }^{55}$.

W kwietniu 1951 r. został przygotowany wstępny, artykułowany projekt prawa spadkowego ${ }^{56}, \mathrm{w}$ maju natomiast zakończono prace nad projektem prawa rzeczowego i projektem części ogólnej prawa obligacyjnego ${ }^{57}$. danie z wykonania planu prac Wydziału Prawa Cywilnego za miesiąc kwiecień 1951 r. (AAN 285, t. 2362, k. 87).

57 t. 2362, k. 91) 
Zbliżał się jednak termin podany w uchwale Prezydium Rządu i presja czasu była coraz silniejsza. W lipcu $1951 \mathrm{r}$. poproszono ministra sprawiedliwości o uzupełnienie sprawozdania z przebiegu prac kodyfikacyjnych za II kwartał przez oświadczenie, czy jego zdaniem dotychczasowy stan i tempo prac kodyfikacyjnych zabezpieczą dotrzymanie terminu przewidzianego w uchwale Prezydium Rządu z 27 września 1950 r. ${ }^{58} \mathrm{~W}$ odpowiedzi minister potwierdził możliwość dotrzymania terminu, asekuracyjnie zastrzegając możliwość niewielkich opóźnień oraz wskazując, że ostateczne dotrzymanie terminu nie jest zależne tylko od pracowników Ministerstwa Sprawiedliwości ${ }^{59}$. Minister wskazał, że "ciągłe i intensywne tempo prac kodyfikacyjnych zmierza do zakończenia tych prac $\mathrm{w}$ terminie określonym $\mathrm{w}$ uchwale Prezydium Rządu z dnia 27.IX.1950 r. W tym kierunku idą wzmożone wysiłki Ministerstwa. Stan obecny tych prac (...) pozwala przypuszczać, że w zasadzie istnieją możliwości dotrzymania zakreślonego terminu. Jednakże końcowe prace redakcyjne i stylizacyjne mogą przeciągnąć się na krótki okres czasu ${ }^{60}$. Zaznaczam, że ukończenie prac kodyfikacyjnych jest w obecnym stadium, po opracowaniu projektów i merytorycznej dyskusji międzyresortowej, zależne głownie od otrzymania ostatecznej aprobaty ze strony zainteresowanych resortów." ${ }^{\prime 1}$

Wiosną 1951 r. pierwsza redakcja projektów poszczególnych działów prawa cywilnego majątkowego była już gotowa. Kolejnym krokiem było poddanie ich dyskusji. Ważną rolę w tym zakresie miało odegrać Zrzeszenie Prawników Polskich (ZPP). Projekty poszczególnych działów cywilnego prawa majątkowego zostały przesłane do Zarządu ZPP w celu ich rozpowszechnienia. Zrzeszenie miało też zorganizować ogólną dyskusję prawników nad założeniami nowego kodeksu cywilnego ${ }^{62}$.

Niezależnie od pomocy ZPP - jak wskazywano w jednym ze sprawozdań ministerialnych - „na łamach prasy prawniczej poświęcano stale odpowiednie miejsce omówieniu problematyki kodyfikacji cywilnej"63. Rzeczywiście, pracownicy i współpracownicy Ministerstwa Sprawiedliwości na szpaltach czasopism branżowych przedstawiali oficjalne podejście do zagadnień kodyfikacyjnych. W „Państwie i Prawie" ukazał się artykuł J. Wasilkowskiego poświęcony

\footnotetext{
58 Pismo S. Rozmaryna - Dyrektora Generalnego I Zespołu Prezydium Rządu do Ministra Sprawiedliwości z 16 lipca 1951 r. (AAN 285, t. 5605, k. 9).

59 AAN 285, t. 5605, k. 11.

60 W roboczej wersji sprawozdania przypuszczano, że prace przeciągną się „na miesiąc wrzesień" (AAN 285, t. 5605, k. 10).

61 AAN 285, t. 5605, k. 11.

62 Sprawozdanie za czas do dnia 8 czerwca br. o pracach nad kodyfikacja prawa cywilnego $i$ zaplanowanie wykonania dalszych prac w tym zakresie (AAN 285, t. 5633, k. 93).

63 Sprawozdanie Departamentu Ustawodawczego z prac w zakresie kodyfikacji prawa karnego $i$ cywilnego (AAN 285, t. 5605, k. 18-21).
} 
problemom własności i innych praw rzeczowych ${ }^{64}$ oraz rozprawa S. Szera dotycząca problematyki prawa spadkowego ${ }^{65}$. Przede wszystkim jednak "odpowiednie" artykuły publikowano w organie prasowym Ministerstwa - periodyku „Nowe Prawo”. Pierwszy apel o szeroką dyskusję kodyfikacyjną ukazuje się zaraz po ogłoszeniu uchwały Prezydium Rządu ${ }^{66}$. W kwietniu 1951 r. pojawia się kolejna próba zachęcenia do zgłaszania uwag pod znaczącym tytułem: Szeroka dyskusja - cenna pomoca w pracy kodyfikacyjnej67. Jak utyskiwała bowiem redakcja, wcześniejszy „apel przyniósł plon niezbyt obfity i to zarówno ilościowo jak i jakościowo"68. Narzekania te nie były chyba jednak do końca uzasadnione, skoro już w kolejnym miesiącu „spośród licznych wypowiedzi na temat kodyfikacji prawa cywilnego", jakie nadesłano do Ministerstwa Sprawiedliwości redakcja - z braku miejsca - przytoczyła ,jedynie wypowiedzi najbardziej typowe" 69 . Nie ulega jednak wątpliwości, że wobec bardzo krótkiego terminu zakreślonego przez uchwałę Prezydium Rządu, czasu na odpowiednią dyskusję - taką, która mogłaby wywrzeć istotny wpływ na projektowane regulacje - w zasadzie nie było. Decydujące znaczenie miały natomiast uzgodnienia $\mathrm{z}$ organami władzy.

Pod koniec maja lub na początku czerwca 1951 r. przesłano projekt prawa spadkowego do merytorycznego uzgodnienia wszystkim ministerstwom, urzędom centralnym, bankom państwowym i innym podmiotom ${ }^{70}$. Projekty prawa rzeczowego i obligacyjnego rozesłano zaś w lipcu $1951 \mathrm{r}$. W przeciągu miesiąca napłynęły wypowiedzi Prezydium Rady Ministrów, większości ministerstw, Państwowej Komisji Planowania Gospodarczego, NBP, PKO i innych instytucji. Po rozpatrzeniu zgłoszonych uwag jeszcze w sierpniu 1951 r. odbyły się w Departamencie Ustawodawczym międzyministerialne konferencje uzgadniające, $\mathrm{w}$ toku których ustalono rozbieżności w poglądach odnośnie do niektórych zagadnień. Po uwzględnieniu wyników tych konferencji, wniosków Komisji Kodyfikacyjnej i uwag Departamentu Nadzoru Sądowego dokonano odpowiednich zmian w projektach. Opracowano wówczas „ostateczną" redakcje projektów prawa rzeczowego, zobowiązaniowego i spadkowego, a także od-

64 J. Wasilkowski, Własność i inne prawa rzeczowe, PiP 1951, z. 5-6, s. 854-876.

65 S. Szer, Z zagadnień prawa spadkowego, PiP 1951, z. 5-6, s. 910-924.

66 NP 1950, nr 10, s. 2.

67 NP 1951, nr 4, s. 1-2.

68 Ibidem, s. 1.

69 Głosy praktyki sądowej. Materiaty do kodyfikacji prawa cywilnego, oprac. A. Krajewski, J. Winiarz, NP 1951, nr 5, s. 49-53.

70 W ocenie Ministerstwa, uwagi które napłynęły, nie stanowiły materiału, który powodowałby konieczność dokonania istotnych zmian w projekcie Sprawozdanie za czas do dnia 8 czerwca br. o pracach nad kodyfikacja prawa cywilnego i zaplanowanie wykonania dalszych prac w tym zakresie (AAN 285, t. 5633, k. 93$)$. 
powiednią nowelizację przepisów ogólnych prawa cywilnego, które miały stać się częścią ogólną kodeksu cywilnego ${ }^{71}$.

Nastąpiła graniczna data 1 września 1951 r. W sprawozdaniu z wykonania planu prac Wydziału Prawa Cywilnego na miesiąc sierpień 1951 r. Naczelnik Wydziału - Seweryn Szer wskazuje: „został opracowany w ostatecznej wersji projekt kodeksu cywilnego wraz z uzasadnieniem do tego projektu"72. Złożono go następnie w Prezydium Rady Ministrów, jednak do końca 1951 roku Komisja Prawnicza przy Prezydium nie podjęła prac nad projektem ${ }^{73}$.

Od września 1951 r. dalsze prace w Wydziale Prawa Cywilnego koncentrują się wokół przygotowania zmian w procedurze cywilnej, w szczególności mających na celu dostosowanie przepisów części szczególnych k.p.c. do projektu kodeksu cywilnego ${ }^{74}$. W zakresie prawa materialnego, w listopadzie $1951 \mathrm{r}$. Wydział przygotował jeszcze projekt przepisów wprowadzających kodeks cywilny $^{75}$, w grudniu zaś opracowano jego drugą redakcję ${ }^{76}$.

Po intensywnym okresie prace nad kodyfikacją prawa cywilnego ulegają spowolnieniu. Na początku 1952 r. odbywają się jeszcze posiedzenia Komisji Kodyfikacyjnej dotyczące głównie części ogólnej prawa cywilnego ${ }^{77}$. Natomiast w Wydziale Prawa Cywilnego plan działań na 1952 r. zdominowała już kodyfikacja procedury cywilnej. W zakresie prac nad prawem cywilnym planowano jedynie zorganizowanie wraz z Komisją Konsultacyjno-Naukową zebrania teoretyków i praktyków poświęconego dyskusji nad projektem kodeksu cywilnego ${ }^{78}$.

Dlaczego prace przebiegały bardzo wolno? Termin wynikający z uchwały Prezydium Rządu nie został narzucony Ministerstwu Sprawiedliwości, wręcz

71 W sierpniu 1951 r. opracowano trzecią i czwartą redakcję projektu prawa zobowiązaniowego oraz trzecią redakcję projektów pozostałych działów majątkowego prawa cywilnego. Sprawozdanie Departamentu Ustawodawczego z prac w zakresie kodyfikacji prawa karnego i cywilnego (AAN 285, t. 5605, k. 18-21).

72 Sprawozdanie z wykonania planu prac Wydziału Prawa Cywilnego na miesiąc sierpień 1951 r. (AAN 285, t. 2362, k. 111).

73 Sprawozdanie Departamentu Ustawodawczego z wykonania planu na IV kwartał 1951 r. (AAN 285, t. 5633, k. 59).

74 Plan pracy Wydziału Prawa Cywilnego na miesiac wrzesien 1951 r. (AAN 285, t. 2362, k. 113); Sprawozdanie z wykonania planu prac Wydziału Prawa Cywilnego za miesiąc wrzesień 1951 r. (AAN 285, t. 2362, k. 114). Plan pracy Wydziału Prawa Cywilnego na IV kwartat 1951 r. (AAN 285, t. 2362, k. 118).

75 Plan pracy Wydziału Prawa Cywilnego na miesiac listopad 1951 r. (AAN 285, t. 2362, k. 123); Sprawozdanie z wykonania planu prac Wydziatu Prawa Cywilnego na miesiac listopad 1951 r. (AAN 285, t. 2362, k. 125).

76 Sprawozdanie z wykonania planu prac Wydziału Prawa Cywilnego na miesiąc grudzień 1951 r. (AAN 285, t. 2362, k. 129).

77 Sprawozdanie Departamentu Ustawodawczego z wykonania planu na I kwartał 1952 r. (AAN 285, t. 5633, k. 65) oraz Sprawozdanie z wykonania planu pracy Wydziału Prawa Cywilnego w kwartale I. 1952 r. (AAN 285, t. 2362, k. 148).

78 Plan pracy Wydziału Prawa Cywilnego na rok 1952 r. (AAN 285, t. 2362, k. 133). 
przeciwnie, wynikał z deklaracji samego ministra w złożonym Prezydium memoriale. Optymistyczna wizja szybkiej kodyfikacji w istocie spowodowała pospieszną i intensywną pracę, duży wysiłek nie tylko pracowników Wydziału Prawa Cywilnego, ale też innych osób z Departamentu Ustawodawczego, Nadzoru Sądowego, Komisji Kodyfikacyjnej Prawa Cywilnego czy Komisji Konsultacyjno-Naukowej. Pospieszne tempo prac odniosło przede wszystkim jeden skutek - minister wywiązał się ze złożonej deklaracji ${ }^{79}$. Władzom natomiast prawdopodobnie nie zależało na uchwaleniu w tym momencie kodeksu cywilnego. Toczyły się już bowiem prace nad nową konstytucją ${ }^{80} \mathrm{i}$ gotowy projekt kodeksu cywilnego musiał „poczekać w kolejce” aż uchwalony zostanie akt wyższego rzędu - ustawa zasadnicza nadająca kierunek całemu dalszemu ustawodawstwu. Obawiano się też zapewne doświadczeń, związanych z pierwszym projektem kodeksu cywilnego z lat 1948-49. Przemiany w życiu politycznym wyprzedzały zmiany w sferze legislacyjnej, zapewne więc w perspektywie szybkiego uchwalenia konstytucji, nie chciano, by nowy kodeks cywilny stał się kolejnym „anachronizmem”.

\section{Bibliografia}

\section{Akty prawne}

Uchwała Rady Ministrów z dnia 12 czerwca 1945 r. w sprawie unifikacji prawa cywilnego, [w:] P. Fiedorczyk, Dokumenty archiwalne dotyczace organizacji prac nad unifikacja $i$ kodyfikacja polskiego prawa cywilnego w latach 1945-1948, „Miscellanea Historico-Iuridica” 2006, t. IV.

Zarządzenie Ministra Sprawiedliwości z dnia 18 lutego 1947 r. w sprawie powołania komisji do opracowania jednolitego polskiego kodeksu cywilnego.

Uchwała Rady Ministrów RP z dnia 11 grudnia 1948 r. o trybie uzgadniania i uchwalania projektów ustaw, dekretów i rozporządzeń.

Ustawa z dnia 27 czerwca 1950 r. - Kodeks rodzinny (Dz. U. Nr 34, poz. 308).

Ustawa z dnia 18 lipca 1950 r. - Przepisy ogólne prawa cywilnego (Dz. U. Nr 34, poz. 311).

Uchwała Prezydium Rządu z dnia 27 września 1950 r. w sprawie opracowania nowych kodeksów Polski Ludowej - karnego i cywilnego (Monitor Polski Nr A-106, poz. 1339).

79 Zagadnienie, $\mathrm{w}$ jakim stopniu przygotowane w $1951 \mathrm{r}$. projekty zostały wykorzystane $\mathrm{w}$ projekcie kodeksu cywilnego opublikowanym w 1954 r., wymaga dalszych badań.

80 Zob. więcej: A. Lityński, Konstytucja 1952 roku a prace nad kodyfikacja prawa cywilnego. Wybrane zagadnienia historycznoprawne, [w:] W kręgu zagadnień konstytucyjnych. Profesorowi Eugeniuszowi Zwierzchowskiemu w darze, red. M. Kudej, Katowice 1999, s. 359-368. 


\section{Archiwalia}

Archiwum Akt Nowych, zespół nr 285 - Ministerstwo Sprawiedliwości w Warszawie, sygn. teczek: 2181, 2190, 2362, 2380, 2382, 5465, 5604, 5605, 5633, $5465,5633$.

Transmisja uroczystości poświęconej zakończeniu prac nad unifikacją prawa cywilnego w Polsce, odbywającej się w gmachu Prezydium Rady Ministrów w Warszawie, NAC, Zespół nagrań dźwiękowych 33-P-787.

\section{Literatura}

„Nowe Prawo" 1950, nr 10.

Czachórski W., Przebieg prac nad kodyfikacja prawa cywilnego PRL, „Studia Prawnicze” 1970, z. 26-27.

Fiedorczyk P., Dokumenty archiwalne dotyczace organizacji prac nad unifikacja i kodyfikacja polskiego prawa cywilnego w latach 1945-1948, „Miscellanea Historico-Iuridica" 2006, t. IV.

Fiedorczyk P., Unifikacja i kodyfikacja prawa rodzinnego w Polsce (1945-1964), Białystok 2014.

Fiedorczyk P., Volkonovski J., Organizacja prac legislacyjnych Rady Ministrów w świetle niepublikowanej uchwały Rady Ministrów z 11 grudnia 1948 r., „Miscellanea Historico-Iuridica" 2011, t. X.

Grodziski S., Prace nad kodyfikacją i unifikacja polskiego prawa prywatnego (1919-1947), „Kwartalnik Prawa Prywatnego" 1992, z. 1-4.

Grodziski S., Z dziejów unifikacji polskiego prawa cywilnego, "Czasopismo Prawno-Historyczne" 1985, z. 2, s. 299.

Gwiazdomorski J., Prawo spadkowe w zarysie, Warszawa 1967.

Konferencja prawników - cywilistów, „Nowe Prawo” 1951, nr 5.

Kowalski P., Z badań nad prawem spadkowym w projekcie kodeksu cywilnego z 1948 r., „Miscellanea Historico-Iuridica” 2013, t. XII.

Krajewski A., Winiarz J., Głosy praktyki sądowej. Materiały do kodyfikacji prawa cywilnego, „Nowe Prawo” 1951, nr 5.

Lityński A., Dwie wielkie transformacje prawa sądowego w Polsce XX wieku. Koncepcje i ich realizacja, [w:] W pięćsetlecie Konstytucji Nihil Novi. Z dziejów stanowienia prawa w Polsce, Warszawa 2006.

Lityński A., Konstytucja 1952 roku a prace nad kodyfikacja prawa cywilnego. Wybrane zagadnienia historycznoprawne, [w:] W kręgu zagadnień konstytucyjnych. Profesorowi Eugeniuszowi Zwierzchowskiemu w darze, red. M. Kudej, Katowice 1999, s. 359-368.

Lityński A., Na drodze do kodyfikacji prawa cywilnego w Polsce Ludowej, [w:] Prawo wczoraj i dziś. Studia dedykowane profesor Katarzynie Sójce-Zielińskiej, Warszawa 2000, s. 135-153. 
Lityński A., Nowe ustawodawstwo w nowym ustroju. O prawie karnym i cywilnym w pierwszym dwudziestoleciu Polski Ludowej, „Miscellanea Historico-Iuridica" 2006, t. IV.

Lityński A., O prawie i sądach początków Polski Ludowej, Białystok 1999.

Lityński A., Pierwszy etap prac nad kodyfikacja prawa cywilnego w Polsce Ludowej (szkic dla dydaktyki), [w:] Z dziejów prawa, cz. 2, Katowice 1999, s. 194-205.

Lityński A., Prawo cywilne materialne w Polsce Ludowej, [w:] Pót wieku kodyfikacji prawa w Polsce (1919-1969). Wybrane zagadnienia, Tychy 2001, s. 87-99.

Pomoc, przykład, przyjaźn ZSRR drogowskazem naszych prac kodyfikacyjnych, "Nowe Prawo" 1950, nr 11.

Radwański Z., Prawo cywilne PRL, „Czasopismo Prawno-Historyczne” 1995, z. 1-2.

Skąpski J., Kodeks cywilny z 1964 r. Blaski i cienie kodyfikacji oraz jej perspektywy, „Kwartalnik Prawa Prywatnego" 1992, z. 1-4.

Szer S., Prawo spadkowe, Warszawa 1955.

Szer S., Z zagadnień prawa spadkowego, „Państwo i Prawo” 1951, z. 5-6.

Szeroka dyskusja - cenna pomoca w pracy kodyfikacyjnej, "Nowe Prawo” 1951, nr 4.

Uchwała Prezydium Rządu dotycząca prac kodyfikacyjnych, „Państwo i Prawo” 1951, z. 1.

Wasilkowski J., Kodyfikacja prawa cywilnego w Polsce, „Nowe Prawo” 1950, nr 12.

Wasilkowski J., Własność i inne prawa rzeczowe, „Państwo i Prawo” 1951, z. 5-6.

Z okazji zakończenia unifikacji prawa cywilnego (akademia), „Demokratyczny Przegląd Prawniczy" 1947, nr 1-2. 